\title{
Relationship among Perceived Stress, Life Satisfaction and Academic Performance of Education Sciences Students of the University of Jaén after the COVID-19 Pandemic
}

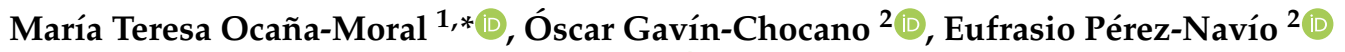 \\ and María del Carmen Martínez-Serrano ${ }^{2}$ (D) \\ 1 Department of Didactic of Sciences, Faculty of Humanities and Education Sciences, University of Jaén, \\ Campus Las Lagunillas, s/n, 23071 Jaén, Spain \\ 2 Department of Pedagogy, Faculty of Humanities and Education Sciences, University of Jaén, Campus Las \\ Lagunillas, s/n, 23071 Jaén, Spain; ogavin@ujaen.es (Ó.G.-C.); epnavio@ujaen.es (E.P.-N.); \\ mcmartin@ujaen.es (M.d.C.M.-S.) \\ * Correspondence: mocana@ujaen.es; Tel.: +34-953-211974
}

check for updates

Citation: Ocaña-Moral, M.T.; Gavín-Chocano, Ó.; Pérez-Navío, E.; Martínez-Serrano, M.d.C. Relationship among Perceived Stress, Life Satisfaction and Academic Performance of Education Sciences Students of the University of Jaén after the COVID-19 Pandemic. Educ. Sci. 2021, 11, 802. https://doi.org/ 10.3390/educsci11120802

Academic Editors:

Marija Kuzmanović and Dragana Makajić-Nikolić

Received: 21 October 2021

Accepted: 3 December 2021

Published: 9 December 2021

Publisher's Note: MDPI stays neutral with regard to jurisdictional claims in published maps and institutional affiliations.

Copyright: (c) 2021 by the authors. Licensee MDPI, Basel, Switzerland. This article is an open access article distributed under the terms and conditions of the Creative Commons Attribution (CC BY) license (https:/ / creativecommons.org/licenses/by/ $4.0 /)$.

\begin{abstract}
The circumstances arising from the exceptional situation caused by the COVID-19 pandemic have affected all socioeconomic areas in the last two years. The field of Education has not been an exception, and the management of the situation seems to have caused an increase in the level of perceived stress of university students. On this basis, this research that aims, first, to analyze the student's level of perceived stress during the de-escalation and return to normality period, secondly, to evaluate its relationship with life satisfaction and, finally, to detect the students' needs in stress management, has been developed. An exploratory-descriptive study of quantitative and cross-sectional nature has been carried out. A total of 222 university students of the Childhood and Primary Education Degrees of the University of Jaén (Spain) have participated. The instruments, Perceived Stress Scale (PSS) and Satisfaction with Life Scale (SWLS) have been used. The results show a moderate and partial relationship among the dimensions of the used instruments. The obtained coefficients of determination are, Academic Performance $\left(r^{2}=0.019\right)$ and Life Satisfaction $\left(r^{2}=0.402\right)$, with a mean square error (SRMR) of 0.079. These findings show the need to develop actions within the university training program in effective stress management strategies.
\end{abstract}

Keywords: perceived stress; life satisfaction; academic performance; university students; stress management; COVID-19

\section{Introduction}

Many students may be exposed to various situations that not only affect their academic performance but also their mental health during their university training stage. In this vital stage, various pathological expressions such as depression, anxiety, feeling down and psychological stress are more frequent and even more serious than in others [1].

Although stress is a response to life changes and acts as a stimulus to take an action, it can be harmful when it becomes habitual and the individual no longer has the ability to address it [2]. This problem is linked to the interaction of various factors, and the university stage is not disconnected to it. In fact, regardless of personal or social causes, there are some reasons owed to the academic life that are significantly associated with stress [3]. The impact of stress on the daily life of students should be studied as an important influence on the educational process since it can affect both the professional training process and its completion [4]. In this reflective analysis, the responsibilities, roles and the educational and personal context of each student should be considered, since these variables could attenuate or accentuate the process of building the capacity to manage stress. Students, in their university stage, face constant challenges, both their own and outside of their training. 
Regarding the academic environment, depending on the development of the student, the work environment, the academic performance and the evaluation carried out, the perceived stimuli may be stressors or not $[5,6]$.

Currently, there is one more possible agent that causes stress in university students: the global COVID-19 pandemic. The authors of [7] indicate that the main factors related to student stress include academic factors such as exam duration, navigation mode and technical problems. Other factors are that the teaching methods have not adequately covered the material, the home testing environment and student dishonesty. There are health factors, too, for example, these authors also detect a decrease in physical activity during this period, which in turn reduces the quality of sleep of the students and affects the performance of the students during the exams.

Some scientific studies on the impact that confinement has had in the psychological field of quarantined populations have been carried out. For example, [8-10], among others, have investigated the variables that are related to perceived stress, such as age, gender, educational level, type of occupation, having people in charge and/or belonging to a population at risk for COVID-19 (or having someone close to you who is risk population).

Ozamiz-Etxebarria et al. [11] carried out a study with the aim of determining the levels of stress, anxiety and depression in the first wave of COVID-19 with a sample made up of 976 citizens from the north of Spain. These researchers found that the youngest group of the study population (18-25 years) had higher averages in stress, anxiety and depression compared to the other two groups (26-60 years and older than 60 ). They also noted that there was a greater psychological impact on those people with chronic illnesses.

León-Montoya el al. [12] developed a study in Mexico to evaluate the levels of anxiety, depression, stress and the perception of their health status in university students after 7 weeks of confinement due to the COVID-19 pandemic. The data obtained by these researchers show that, during the confinement phase, practically a quarter of the study population, regardless of the sociodemographic variables, presented headache sense, a feeling of lack of control and little satisfaction with the way of performing their tasks. In addition, approximately a third of the population said that they felt overwhelmed, nervous, bad-tempered, less active, spending more time than usual performing daily tasks and with worthless feelings.

On the other hand, [10] carried out a study in Argentina, with a population made up of 6355 individuals aged 18 to 85 regarding the influence of the educational level on the effects of COVID-19 on people's stress. They found that people with university studies experienced lower levels of stress than people with primary education or without studies, pointing out that these results could be due to the fact that people with higher educational levels have greater access to better tools and skills to tolerate uncertainty and face the stress of a context such as the current one.

In Italy, [9] conducted a survey on the web and conducted by 18,147 people $(79.6 \%$ women) and found that, 3 weeks after the COVID-19 blocking measures, there had been high rates of negative mental health results in the Italian general population and different risks related to COVID-19, such as depression, anxiety, insomnia or perceived stress, among others.

Similar studies have been carried out worldwide; for example, in China, [13] developed an investigation with a big sample of students during the first wave of the COVID-19 pandemic. This study showed that the individuals surveyed had developed similar symptoms to depression, anxiety and stress. It also showed a significant association among self-assessed health status with higher levels of stress, anxiety and depression, especially in female students. Along the same lines, [14] identified the presence of feelings of anxiety (35.1\%), depression (20.1\%) and problems in sleep quality (18.2\%) during the first phase of confinement due to COVID-19 in a Chinese population.

All this confirms that experiences such as anxiety, stress, panic attacks, sleep disorders, anger or disappointment, among others of the kind, are manifested in people due to confinement during pandemics [15]. This indicates that the consequences of the COVID-19 
pandemic can lead to many psychological problems that can influence people's quality of life [16]. However, we still know little about the influence of the COVID-19 pandemic on the life satisfaction of university students and what factors increase or decrease this feeling. Many previous studies have shown that stress has a negative influence on the well-being and vital attitude of people. People experience emotional exhaustion, negative emotions, and less vitality in stressful situations [17]. However, up until now, little research has been published on the impact of the COVID-19 pandemic on people's life satisfaction.

The abovementioned allowed us to realize that stress is a relevant variable in order to advance in the understanding of how the pandemic influences the people's life satisfaction in general and specifically on university students who are usually very concerned about the assessment of their academic performance. Thus, in the present study, we set out to analyse the relationship between perceived stress, life satisfaction and academic performance of Education Sciences students at the University of Jaén after the COVID-19 pandemic and during the onset of de-escalation, which started on September 20 at the University of Jaén [18].

To do this, Structural Equation Modelling (SEM) has been used. There are two approaches: The first is based on Covariance-Based Structural Equation Modelling (CB-SEM), which is recommended when contrasting theories, testing hypotheses or when designing new theories. The second is the Partial Least Squares Structural Equation Modelling approach, based on the analysis of variance [19].

Furthermore, as indicated by [20,21], PLS-SEM is a multivariate analysis approach that is used to estimate models with latent variables. It is a recommended technique when, as in this study:

- The objective is the prediction of a target construct, or it is intended to identify relevant constructs.

- The research model is complex depending on the type of relationships that are hypothesized (direct and mediated).

- The constructs that are part of the structural model have been designed following a formative measurement model.

- $\quad$ The structural model is complex.

- The sample size is small.

- The data do not have a normality distribution.

In accordance with the above, the PLS regression of the route model is used, because it is a more flexible methodology (not requiring rigorous parametric assumptions), especially in the data distribution and sample size. The first step was to develop the theoretical model (Figure 1), where these three variables (perceived stress, life satisfaction and academic performance) are collected, and the causes that specify how and why they are related are explained.

The only starting hypothesis (H1) is the existence of a causal relationship between perceived stress and life satisfaction as predictive values of academic performance and expectations for improvement.

Both variables have been measured through the data on the academic results obtained during the pandemic and the beginning of the de-escalation and the expectations of improvement in the beginning of normality (face-to-face classes).

Based on the above, the objectives of this study were the following:

(a) Study the existence of statistically significant correlations among the dimensions of the assessment for perceived stress (PSS-14), life satisfaction (SWLS) and academic performance;

(b) Establish the existence of significant differences between the dimensions of the instruments considered and the sociodemographic variables (gender and educational level);

(c) Analyse the causal relationship of perceived stress and life satisfaction on academic performance. 


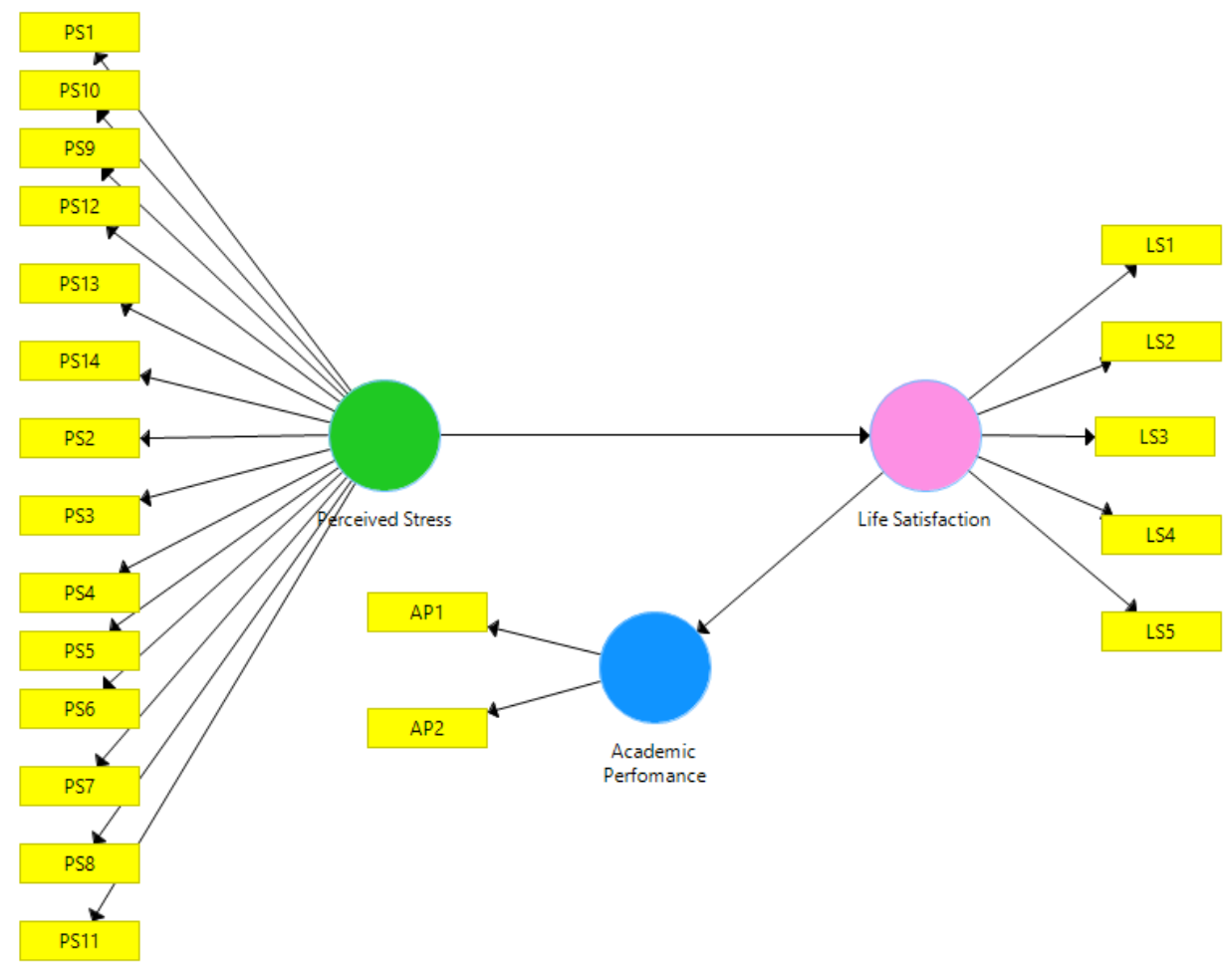

Figure 1. Initial causal model of perceived stress, life satisfaction and academic performance.

\section{Materials and Methods}

The present research is based on a quantitative, cross-sectional, non-experimental and correlational analysis. Based on these criteria, longitudinal, comparative and reliability measures are established through Cronbach's alpha and Omega coefficient [14], also called Jöreskog's Rho [15].

\subsection{Procedure}

The questionnaire was distributed, and the data were collected among the students of the Childhood and Primary Education Degrees of the University of Jaén (Spain) in September 2021 using the Google Form tool. Before it was carried out, an "explanatory sheet "was presented to the students, where the essential aspects of the research were indicated: who the researchers are, its purpose (study objectives) and its anonymity, confidentiality and voluntariness.

\subsection{Sample}

The sample is made up of 222 university students of the Childhood Education and Primary Education Degrees, belonging to the Faculty of Humanities and Sciences Education of Jaén (Spain). The selection of the sample was non-probabilistic and incidental. As shown in Table 1, the distribution of the participants $(n=222)$ by the taken degree is as follows: 184 study Childhood Education (82.08\%) and 38 study Primary Education (17.12\%). Regarding the gender: 171 are women, (77.03\%) and 51 men (22.97\%). The gender variable has specifically been studied because, as the data from the University of Jaén show, the male/female ratio in these degrees is one of its differentiating characteristics, at least in this university, since there are always many more female than male students.

On the other hand, the average age of the participants is $22.02( \pm 3.97)$, and the average grade during the pandemic (2020/2021 course) is $8.59( \pm 8.88)$. 
Table 1. Percentage of respondents by degree and gender.

\begin{tabular}{ccc}
\hline & Degree \\
\hline Childhood Education & Primary Education \\
\hline $82.08 \%$ & $17.12 \%$ \\
\hline Female & Mender \\
\hline $77.03 \%$ & & Male \\
\hline
\end{tabular}

\subsection{Research Model}

Partial Least Squares (PLS) technique was used to evaluate the proposed model. The structural design was analysed to determine its validity, dimensionality and reliability. The convergent validity, the factor loadings, the variance and the composite reliability were analysed, too [22].

Figure 2 shows the results obtained (threshold of 0.6) according to the criteria of [23]. The results show a partial convergent validity of the proposed model.

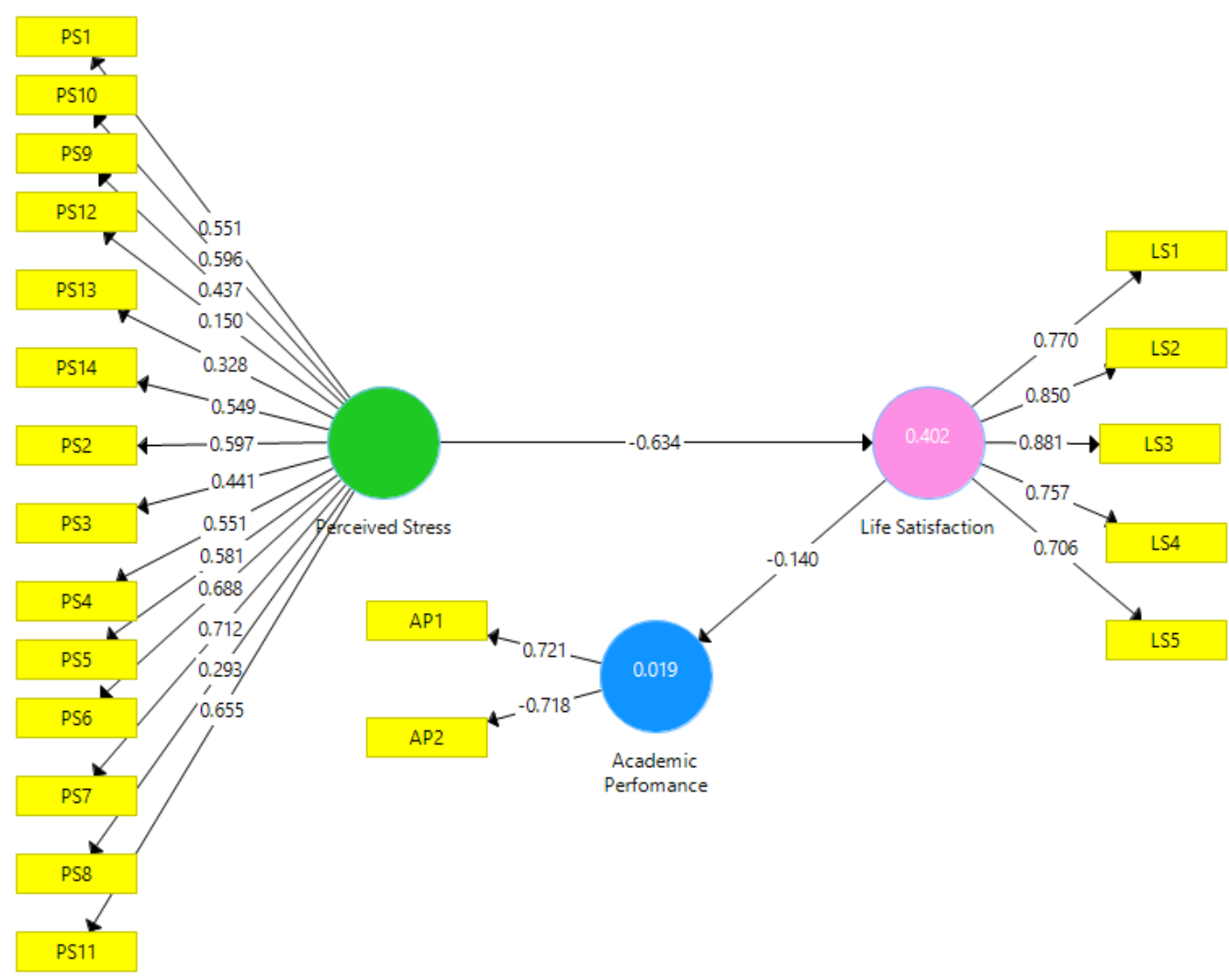

Figure 2. Causal model of Emotional Intelligence, Quality of Life and Life Satisfaction.

\subsubsection{Reliability and Validity of the Model}

Table 2 shows Cronbach's alpha, Omega coefficient, external loads and the grades of the composite reliability index (CRI). In relation to the convergent validity obtained through the estimation of the average variance extracted (AVE), the values must be greater than 0.5, according to the criteria of [24]. That is, an AVE's high value will have a better representation of the load of the observable variable. 
Table 2. Research model results.

\begin{tabular}{cccccc}
\hline Variable & $\boldsymbol{\alpha}$ & $\omega$ & $\begin{array}{c}\text { Composite Reliability } \\
\text { Index (CRI) }\end{array}$ & Rho_A & $\begin{array}{c}\text { Mean Extracted } \\
\text { Variance (MEV) }\end{array}$ \\
\hline PS & 0.79 & 0.80 & 0.83 & 0.84 & 0.283 \\
LS & 0.84 & 0.86 & 0.89 & 0.87 & 0.633 \\
AP & - & - & - & - & 0.517 \\
\hline
\end{tabular}

Note: (1) Perceived Stress = PS; Life Satisfaction = LS; Academic Performance = AP.

\subsubsection{Cross Factorial Loads}

Table 3 shows the discriminant validity or level at which the elements differ, that is, when it is considered that there is a difference between variables [25].

Table 3. Cross factorial loads.

\begin{tabular}{cccc}
\hline Variable & Academic Performance (AP) & Life Satisfaction (LS) & Perceived Stress (PS) \\
\hline AP1 & $\mathbf{0 . 7 2 1}$ & -0.101 & 0.062 \\
AP2 & $-\mathbf{0 . 7 1 8}$ & 0.100 & -0.025 \\
LS1 & -0.078 & $\mathbf{0 . 7 7 0}$ & -0.496 \\
LS2 & -0.158 & $\mathbf{0 . 8 5 0}$ & -0.523 \\
LS3 & -0.160 & $\mathbf{0 . 8 8 1}$ & -0.599 \\
LS4 & -0.114 & $\mathbf{0 . 7 5 7}$ & -0.453 \\
LS5 & -0.020 & $\mathbf{0 . 7 0 6}$ & -0.432 \\
PS1 & 0.005 & -0.270 & $\mathbf{0 . 5 5 1}$ \\
PS2 & 0.055 & -0.359 & $\mathbf{0 . 5 9 7}$ \\
PS3 & -0.034 & -0.231 & $\mathbf{0 . 4 4 1}$ \\
PS4 & -0.016 & -0.303 & $\mathbf{0 . 5 5 1}$ \\
PS5 & 0.032 & -0.400 & $\mathbf{0 . 5 8 1}$ \\
PS6 & 0.047 & -0.358 & $\mathbf{0 . 6 8 8}$ \\
PS7 & 0.099 & -0.628 & $\mathbf{0 . 7 1 2}$ \\
PS8 & 0.042 & -0.076 & 0.293 \\
PS9 & -00.80 & -0.188 & $\mathbf{0 . 4 3 7}$ \\
PS10 & -0.020 & -0.351 & $\mathbf{0 . 5 9 6}$ \\
PS11 & 0.117 & -0.444 & $\mathbf{0 . 6 5 5}$ \\
PS12 & -0.084 & -0.087 & 0.150 \\
PS13 & -0.120 & -0.170 & $\mathbf{0 . 3 2 8}$ \\
PS14 & 0.131 & -0.310 & $\mathbf{0 . 5 4 9}$ \\
\hline
\end{tabular}

Note: (1) Academic Performance $=$ AP, Life Satisfaction $=$ LS, Perceived Stress = PS. (2) Values in bold indicate values $>0.4$.

The square root of the mean variance obtained is indicated in bold. This value must be higher than the values in each row and column respectively. To analyse the discriminant validity, factor loadings and cross factor loadings were obtained [26], knowing that-for there to be difference between variables-the factor loadings must be higher than the loads' cross factorials [22]. Therefore, according to the theory, the indicators have to be more correlated with their own construct than with the others [25]. According to [20], these values (which must be $>0.4$ ), were obtained by comparing the external loads of each indicator of the associated construction compared to the rest of indicators.

\subsubsection{Hypothesis Contrast}

Table 4 shows the results of the path coefficient (standardized regression coefficient), following the criteria of [20], where the causal relationship with the latent variables can be observed. 
Table 4. Path coefficient (standardized regression coefficient).

\begin{tabular}{|c|c|c|c|c|c|c|}
\hline \multicolumn{3}{|c|}{ Relationship between Variables } & \multirow{2}{*}{$\begin{array}{c}\begin{array}{c}\text { Path } \\
\text { Coefficient }(\boldsymbol{\beta})\end{array} \\
0.721\end{array}$} & \multirow{2}{*}{$\begin{array}{c}\begin{array}{c}\text { Standard } \\
\text { Deviation }(\sigma)\end{array} \\
0.657\end{array}$} & \multirow{2}{*}{$\begin{array}{c}\text { t Statistic } \\
1.097\end{array}$} & \multirow{2}{*}{$\begin{array}{c}p \\
0.273\end{array}$} \\
\hline AP1 & $\leftrightarrow$ & Academic Performance & & & & \\
\hline AP2 & $\leftrightarrow$ & Academic Performance & -0.718 & 0.683 & 1.051 & 0.294 \\
\hline LS1 & $\leftrightarrow$ & Life Satisfaction & 0.770 & 0.042 & 18.188 & $* * *$ \\
\hline LS2 & $\leftrightarrow$ & Life Satisfaction & 0.850 & 0.022 & 39.497 & $* * *$ \\
\hline LS3 & $\leftrightarrow$ & Life Satisfaction & 0.881 & 0.017 & 52.616 & $* * *$ \\
\hline LS4 & $\leftrightarrow$ & Life Satisfaction & 0.757 & 0.036 & 20.769 & $* * *$ \\
\hline LS5 & $\leftrightarrow$ & Life Satisfaction & 0.706 & 0.042 & 16.791 & $* * *$ \\
\hline PS1 & $\leftrightarrow$ & Perceived Stress & 0.551 & 0.062 & 8.865 & $* * *$ \\
\hline PS2 & $\leftrightarrow$ & Perceived Stress & 0.597 & 0.062 & 9.598 & $* * *$ \\
\hline PS3 & $\leftrightarrow$ & Perceived Stress & 0.441 & 0.075 & 5.840 & $* * *$ \\
\hline PS4 & $\leftrightarrow$ & Perceived Stress & 0.551 & 0.062 & 8.922 & $* * *$ \\
\hline PS5 & $\leftrightarrow$ & Perceived Stress & 0.581 & 0.059 & 9.894 & $* * *$ \\
\hline PS6 & $\leftrightarrow$ & Perceived Stress & 0.688 & 0.048 & 14.207 & $* * *$ \\
\hline PS7 & $\leftrightarrow$ & Perceived Stress & 0.712 & 0.033 & 21.473 & $* * *$ \\
\hline PS8 & $\leftrightarrow$ & Perceived Stress & 0.293 & 0.088 & 3.336 & $* * *$ \\
\hline PS9 & $\leftrightarrow$ & Perceived Stress & 0.437 & 0.077 & 5.708 & $* * *$ \\
\hline PS10 & $\leftrightarrow$ & Perceived Stress & 0.596 & 0.067 & 8.950 & $* * *$ \\
\hline PS11 & $\leftrightarrow$ & Perceived Stress & 0.655 & 0.044 & 15.023 & $* * *$ \\
\hline PS12 & $\leftrightarrow$ & Perceived Stress & 0.150 & 0.086 & 1.735 & 0.083 \\
\hline PS13 & $\leftrightarrow$ & Perceived Stress & 0.328 & 0.086 & 3.803 & $* * *$ \\
\hline PS14 & $\leftrightarrow$ & Perceived Stress & 0.549 & 0.062 & 8.880 & $* * *$ \\
\hline
\end{tabular}

Note: Life Satisfaction $=$ LF, Emotional Intelligence $=$ EI, Quality of Life $=$ QL. $(2)^{*}=p<0.05{ }^{* *}=p<0.01 ;{ }^{* * *}=p<0.001$.

The $t$-test was obtained (according to the bibliography, values higher than 1.96 indicate the coherence of the model). In this case, all the values obtained higher than 1.96 except for those refer to the academic performance and the expectations for improvement. Data indicate that there is a significant negative relationship, as expected, between perceived stress and life satisfaction, with no causal relationship with academic performance and expectations for improvement. Therefore, the results obtained show the partial validity of the model.

According to [12], $r^{2}$ was used to measure the effect size, being the determination coefficient for Academic Performance and Life Satisfaction: $r^{2}=0.019$ and $r^{2}=0.402$, respectively, with a Standarized Root Mean-Square (SRMR) of 0.079. As indicated in the bibliography [27], a value of SRMR $<0.08$ is considered acceptable, and an SRMR $<0.05$ is considered optimal.

\subsection{Instrument}

As stated above, the research includes two sociodemographic variables in order to collect relevant information based on gender and degree studied and in order to analyse the possible existence of significant differences based on these.

Satisfaction with Life Scale (SWLS) and Perceived Stress Scale (PSS) unified in a single instrument of 19 items were used to measure life satisfaction and perceived stress, respectively.

First, to assess life satisfaction, the SWLS [28] was used, specifically, the version of the Satisfaction with Life Scale by [29]. It is made up of five items (Table 5) where participants must indicate the degree of agreement or disagreement for each of the response options of the instrument. The scale in the Spanish version has an internal consistency of $\alpha=0.82$. The reliability of the scale scores in our sample is $\alpha=0.84$, and the Omega coefficient $\omega=0.86$.

Secondly, to assess the students 'perceived stress the PSS [30,31] was used. This scale is made up of 14 items (Table 6), 7of which are in favour of control (e.g., "How often have I felt like I had everything under control?") and, another 7 in favour of loss of control (e.g., "How often have I been angry because things that happened to me were out of my 
control?"). In the factor in favour of control, the scores of items 4, 5, 6, 7, 9, 10 and 13 are inverted to assess the stress.

Table 5. Satisfaction with Life Scale ([29] version).

\section{SWLS}

1. My life is how I want it to be in most aspects.

2. My life circumstances are very good.

3. I am satisfied with my life.

4. So far, I have achieved the things that I consider important from life.

5. If I could live my life again, I would not change almost anything.

Table 6. Perceived Stress Scale [30,31].

\section{PSS}

1. How often have I been affected by something that happened unexpectedly?

2. How often have I felt unable to control the important things in my life?

3. How often have I felt nervous or stressed?

4. How often have I successfully dealt with life's irritating little problems?

5. How often have I felt that I have effectively coped with the major changes that have been taking place in my life?

6. How often have I been confident about my ability to handle my personal problems?

7. How often have I felt that things are going well for me?

8. How often have I felt like I could not face all the things I had to do?

9. How often have I been able to control the difficulties in my life?

10. How often have I felt like I had everything under control?

11. How often have I been angry because things that happened to me were out of my control?

12. How often have I thought about the things that I still have to do?

13. How often have I been able to control the way I spend time?

14. How often have I felt difficulties accumulate so much that I cannot overcome them?

Items are evaluated using a 7-degree Likert-type gradient frequency scale: $1=$ Strongly disagree, 2 = Quite disagree, $3=$ Disagreement, $4=$ Neither Agree nor Disagree, $5=$ Agreement, $6=$ Pretty much agree, $7=$ Totally agree. The global score is obtained by adding the reversal of the scores of the positive items (characterized by having a positive statement) and the scores of the negative items [32].

The reliability of the scale scores in our sample is $\alpha=0.79$, and the Omega coefficient is $\omega=0.80$.

Taking into account the average grade obtained during the pandemic (2020/2021 academic year) and the expectations for improvement during the 2021/2022 academic year (in which the Childhood Education Degree and Primary Education Degree students have returned to face-to-face classes), the academic performance indicator is considered good to measure the academic aptitudes of university students in a global and precise way.

\subsection{Data Analysis}

Data from the survey were encoded and analysed using the SPSS 25.0 (IBM, Chicago, IL, USA) and SmartPLS 3.3., using a confidence level of 95\% (significance $p<0.05$ ), to obtain the results of the tests indicated below.

Descriptive statistics (means and standard deviations) were obtained, analysing a priori the reliability and internal consistency of each instrument (Cronbach's alpha and Omega coefficient) when working on the weighted sum of each variable and thus being able to overcome the limitations that could affect to the proportion of the variance [33] and to the correlation between the resulting scores in each of the dimensions.

Next, a mean difference analysis according to gender and coursed Degree (Childhood Education or Primary Education) was developed using the Mann-Whitney U test of range difference for unrelated samples. Non-parametric tests have been used because 
the normality assumption was not fulfilled in all cases based on the data obtained in the Kolmogorov-Smirnov test. In addition, the effect size in the analyses performed is reported

Finally, the Partial Least Squares (PLS) approach was used to evaluate the theoretical model under study, having previously analysed the latent variables (dimensionality, validity and reliability) with a Confirmatory Factor Analysis (CFA).

\section{Results}

The results obtained in accordance with the objectives of the investigation are shown below.

\subsection{Relationship among Perceived Stress, Life Satisfaction and Academic Performance}

Table 7 shows the scores of the correlation matrix, descriptive statistics (mean, $\mathrm{M}$ and standard deviation, SD), reliability analysis (Cronbach's alpha, $\alpha$, and Omega coefficient, $\omega$ ), where it can be observed, as expected, a statistically significant and negative relationship between the variables perceived stress and life satisfaction $\left(r_{(222)}=-0.543 ; p<0.01\right)$.

Table 7. Internal consistency, mean, standard deviation and Spearman's Rho correlation of the variables "perceived stress", "life satisfaction" and "academic performance".

\begin{tabular}{ccccccc}
\hline Variable & $\alpha$ & & $\boldsymbol{M}(S D)$ & Perceived Stress & Life Satisfaction & Academic Performance \\
\hline Perceived Stress & 0.79 & 0.80 & $5.054( \pm 0.962)$ & - & $-0.543^{* *}$ & -0.034 \\
Life Satisfaction & 0.84 & 0.86 & $2.962( \pm 0.414)$ & - & -0.191 \\
Academic Performance & - & - & $8.597( \pm 8.881)$ & & - \\
\hline
\end{tabular}

Note: (1) Mean $=M$, Standard Deviation $=S D,(2)^{* *}=p<0.01$.

\subsection{Differences Based on Sociodemographic Variables}

\subsubsection{Sociodemographic Variable "Gender"}

The nonparametric Mann-Whitney $U$ test for two independent samples was used to analyse the differences based on the sociodemographic variable gender (Table 8).

Table 8. Rank differences based on gender (Mann-Whitney U).

\begin{tabular}{|c|c|c|c|c|c|}
\hline Variables & $\begin{array}{c}\text { Women } \\
(n=171) \\
M(S D)\end{array}$ & $\begin{array}{l}\text { Men } \\
(n=51) \\
M(S D)\end{array}$ & $Z$ & $p$ & $\begin{array}{c}\text { Size Effect } \\
(r)\end{array}$ \\
\hline $\begin{array}{c}\text { Perceived Stress } \\
\text { Life satisfaction } \\
\text { Academic Performance }\end{array}$ & $\begin{array}{c}2.982( \pm 0.417) \\
5.037( \pm 0.994) \\
8.962( \pm 10.088)\end{array}$ & $\begin{array}{l}2.894( \pm 0.400) \\
5.109( \pm 0.854) \\
7.373( \pm 0.768)\end{array}$ & $\begin{array}{l}-1.433 \\
-0.203 \\
-2.472\end{array}$ & $\begin{array}{l}0.152 \\
0.839 \\
0.013 \\
*\end{array}$ & $\begin{array}{l}0.132 \\
0.018 \\
0.222\end{array}$ \\
\hline
\end{tabular}

Note: (1) Mean $=M$; Standard Deviation $=S D(2) Z=$ Mann-Whitney U test; $p=$ significance (3) Statistical effect size is expressed using Cohen's value. (3) ${ }^{*}=p<0.05$.

The results show that there are no significant differences between the variables perceived stress and life satisfaction in relation to gender $(Z<2.0 ; p>0.05 \mathrm{~ns})$. On the contrary, there are significant differences between the variable academic performance and gender $(Z=-2.472 ; p=0.013)$. The value of $r$ is used to calculate the effect size for this nonparametric test $[r=Z / \sqrt{ } n]$. From the results obtained, it can be stated that, in this study, the effect size is small in all cases $(r<0.2)$ according to Cohen's criteria (1988).

\subsubsection{Sociodemographic Variable "Taken Degree"}

As in the previous case, the nonparametric Mann-Whitney $U$ test for two independent samples was used to analyse the differences based on the sociodemographic variable of taken degree (Childhood Education and Primary Education) (Table 9). 
Table 9. Rank differences based on the taken degree (Mann-Whitney U).

\begin{tabular}{cccccc}
\hline Variables & $\begin{array}{c}\text { Childhood } \\
\text { Education } \\
\boldsymbol{M}(\boldsymbol{S D})\end{array}$ & $\begin{array}{c}\text { Primary } \\
\text { Education } \\
\boldsymbol{M}(\boldsymbol{S D})\end{array}$ & $\mathbf{Z}$ & $\boldsymbol{p}$ & Size Effect $(\boldsymbol{r})$ \\
\hline Perceived Stress & $2.958( \pm 0.415)$ & $2.981( \pm 0.416)$ & -0.101 & 0.919 & 0.010 \\
Life satisfaction & $5.038( \pm 0.969)$ & $5.131( \pm 9.38)$ & -0.651 & 0.515 & 0.066 \\
Academic Performance & $7.925( \pm 0.787)$ & $8.564( \pm 5.468)$ & -2.017 & $\begin{array}{c}0.044 \\
*\end{array}$ & 0.206
\end{tabular}

Note: (1) Mean $=M$; Standard Deviation $=S D(2) Z=$ Mann-Whitney U test; $p=$ significance (3) Statistical effect size is expressed using Cohen's value. (3) ${ }^{*}=p<0.05$.

The results show that there are no significant differences between the variables perceived stress and life satisfaction in relation to the taken Degree $(Z<2.0 ; p>0.05 \mathrm{~ns})$. On the contrary, there are significant differences between the variable academic performance and taken degree $(Z=-2.017 ; p=0.044)$. The value of $r$ is used to calculate the effect size for this nonparametric test $[r=Z / \sqrt{ } n]$. From the results obtained, it can be stated that, in this study, the effect size is small in all cases $(r<0.2)$ according to Cohen's criteria (1988).

\section{Discussion}

The first objective of this research was to study the existence of statistically significant correlations among the dimensions perceived stress and life satisfaction in Childhood and Primary Education Degrees students at the University of Jaén (Spain) after the COVID-19 pandemic and if these dimensions could be used as predictive values of academic performance and expectations for improvement. Each of these relationships received empirical support, assuming that university students perceive the stress in a positive or negative way depending on their emotional state and context to face problems adaptively [34]. Overall, the obtained results show that perceived stress is negative and significantly related to life satisfaction but not to academic performance.

Related to this objective, the results showed that perceived stress significantly correlated with life satisfaction in a negative way. These results coincide with what was stated by other authors such as [35], who found that adaptability to the university context is conditioned, directly and indirectly, with life satisfaction, or [36], who states that students' perceived stress, their physical appearance and positive or negative daily events are predictive of life satisfaction.

Regarding the second objective, "establish the existence of significant differences between the dimensions of the instruments considered and the sociodemographic variables (gender and educational level)", first, and taking into account the size of the sample, no significant differences were found between life satisfaction and gender.

With regard to the perceived stress and gender, no significant differences have been found between them, although it is observed that women obtain slightly higher scores in relation to the perceived stress, and men score higher in life satisfaction. The difference obtained in the data on perceived stress between men and women may be conditioned by the current situation due to the COVID-19 pandemic and with the different ways that women and men have of facing the constant challenges of university education such as previous works corroborate. So, in the academic field, [37,38] observed that according to the student's development, the perceived stimuli may or may not be stress generators, estimating that male students presented lower levels of stress than female ones.

As regards the relationship between perceived stress and life satisfaction with the sociodemographic variable educational level (Childhood or Primary Degree), given the heterogeneity of the sample of this study and the cross-sectional nature of our data, the results are not conclusive. Nevertheless, taking into account the difference between female and male students of both grades, the data show a greater difference in those of Primary Education Degree. Studies such as that of [39] indicate that the educational level can be a determining factor of greater perceived stress. This fact may also be related to the level of demand required to develop the lessons during the COVID-19 pandemic. On the other 
hand, the few studies developed in Spain with the university population have shown that in the academic environment, the student's own development, the academic performance and the evaluation carried out can be determining factors for a positive and significant change in the student's levels of stress and satisfaction vital [5]. Thus, the data indicate that, currently, the level of demand before, during and after the COVID-19 pandemic has resulted in high levels of stress among students, especially women [13,14].

Finally, regarding the causal relationship between perceived stress and life satisfaction with the academic performance, the data were analysed using the Partial Least Squares approach (PLS) and assessed using the convergent validity through the estimation of the Average Variance Extracted (AVE). A partial and moderate fit of the model has been obtained. However, it should be noted that despite the veracity of the data obtained and the simplicity of the proposed model, the sample size and its representativeness do not guarantee that the results can be generalized $[40,41]$. This fact has led a debate in the literature on structural models that try to ratify this causal relationship. However, the statistical "goodness" of the model is that it is based on simple measurements and that it allows corroborating the initial hypothesis about the fit of the model [42,43]. In addition, given that it does not requires rigorous parametric assumptions, especially in the distribution of the data, the Partial Least Squares (PLS) modelling does not require the conditions required in traditional models of structural equations with respect to the normality of the data and size of the sample using nonparametric tests $[20,25,44]$.

Thus, the obtained results show the effect of perceived stress on life satisfaction to achieve higher academic performance: On the one hand, perceived stress has a direct negative relationship on life satisfaction; however, this trend decreases when it is related to academic performance and the perception of improvement in university students. These observations are consistent with what was stated in the study by $[10,44,45]$. These researchers indicate that perceived stress could clearly explain the situation experienced by the students during their period of confinement due to the COVID-19 pandemic, since they not only not had to go to class but also observed that the level of academic demand was lower in relation to the assessment of the subjects taken in previous years. Therefore, the relationship between levels of perceived stress and life satisfaction during the COVID-19 pandemic is not conclusive with the academic results obtained.

Finally, we cannot fail to mention the limitations of this study, among which are: (a) the size of the sample, (b) the greater number of women compared to men and (c) the limitation of the measurement instruments. This implies that it is necessary to develop further research with greater heterogeneity in terms of gender, educational level and preand post-pandemic incidence in the academic performance to favour the generalization of the results and conclusions.

Despite these limitations, this research allows us to state that stress acts as a response to the different vital changes, serving as a stimulus/response in the way of adapting to each situation. However, it is confirmed that stress is harmful when a given situation becomes frequent and the individual is no longer able to manage it. Although there are studies on the prevalence of academic stress [46], most of them were carried out in students of Health Sciences and related studies. Therefore, this research allows us to deepen understanding on how this phenomenon has affected Education students during the COVID-19 pandemic and thus be able to implement measures to alleviate possible deficiencies due to the change in the teaching model (from face-to-face to online).

The practical implications of this research are relevant to analyse the incidence of perceived stress during the pandemic and de-escalation periods in university students. Specifically, the importance of the findings of this study is that, if replicated, it could serve as a guideline to implement techniques to cope with stress in the university context. The elaboration of instruments and resources should consider the acquisition of personal, emotional and social competences, since these have a greater impact on university students' life satisfaction and academic performance. 


\section{Conclusions}

This research shows, first, that perceived stress is negative and significantly related to life satisfaction but not to academic performance for the Education Sciences students of the University of Jaén. Secondly, no significant differences have been found between the perceived stress and gender, although it is observed that women obtain slightly higher scores in relation to the perceived stress, and men score higher in life satisfaction. In the same vein, the data indicate that, currently, the level of demand before, during and after the COVID-19 pandemic has resulted into high levels of stress among students, especially women.

On the other hand, the obtained results show that the perceived stress has a direct negative relationship on life satisfaction, although this trend decreases when it is related to academic performance and the perception of improvement in university students. Finally, we can conclude that the relationship between levels of perceived stress and life satisfaction during the COVID-19 pandemic is not conclusive with the academic results obtained.

The importance of the results of this study is that it can be used as a guideline to implement techniques to reduce the level of stress in future research on perceived stress, life satisfaction and its relationship with academic performance. The development of intervention programs should emphasize personal, emotional and social skills and competencies, since these have a greater impact on life satisfaction and academic performance. In this sense, we believe that more studies related to this issue should be carried out. The data obtained will allow administrations to develop interventions (economic, instrumental, educational, social, etc.) that facilitate the implementation of training actions that reduce the level of perceived stress in the university context. This agrees with $[47,48]$, who state that the administrative department needs to take effective prevention measures to spread positive information that allow the development of good life habits and a healthy lifestyle during confinement. In addition, schools play an important role in the development of students' social relationships by giving them the opportunity to interact with teachers and other students.

It is important to note that the results of this research are only applicable to the sample studied and, at most, to the closest population (students from the University of Jaén, from different Andalusian universities and, probably, to the Spanish university population in general). This is a cross-sectional study, and the lack of a prior assessment to confinement for COVID-19 of the participants makes it impossible to determine a causal relationship between the variables. Given that the characteristics of the sample partially limit the conclusions, we think that it is necessary to include a greater heterogeneity in gender, educational level and socioeconomic background of the participants to facilitate the generalization of the results for future research.

Based on the results obtained, we think that it is desirable to continue analysing the level of perceived stress, life satisfaction and their relationship with academic performance to evaluate the type of relationship among them and strengthen the scientific evidence in the university context during the de-escalation period after the COVID-19 pandemic and thus be able to implement measures to solve the problem.

Author Contributions: Conceptualization, M.d.C.M.-S., Ó.G.-C. and E.P.-N.; methodology, M.d.C.M.S., Ó.G.-C. and M.T.O.-M.; software, Ó.G.-C., M.d.C.M.-S. and M.T.O.-M.; validation, M.T.O.-M., Ó.G.-C. and E.P.-N.; formal analysis, M.T.O.-M., Ó.G.-C. and M.d.C.M.-S.; investigation, Ó.G.-C., M.T.O.-M., M.d.C.M.-S. and E.P.-N.; resources, E.P.-N., Ó.G.-C., M.T.O.-M. and M.d.C.M.-S.; data curation, E.P.-N., M.T.O.-M. and M.d.C.M.-S.; writing—original draft preparation, E.P.-N., M.T.O.-M., Ó.G.-C. and M.d.C.M.-S.; writing-review and editing, Ó.G.-C., M.T.O.-M., E.P.-N. and M.d.C.M.-S.; visualization, E.P.-N., M.T.O.-M. and M.d.C.M.-S.; supervision, M.d.C.M.-S., Ó.G.-C., M.T.O.-M. and E.P.-N.; project administration, E.P.-N., M.T.O.-M., Ó.G.-C. and M.d.C.M.-S.; funding acquisition, Ó.G.-C., M.d.C.M.-S., M.T.O.-M. and E.P.-N. All authors have read and agreed to the published version of the manuscript. 
Funding: This research was funded by University of Jaén, grant number PID64_201617, and the Research Project Code EDU2015-70491-R. The APC was funded by University of Jaén and Ministry of Science and Technology.

Institutional Review Board Statement: This research has been approved by the ethics Committee of the University of Jaén. Code: OCT.20/1. TES.

Informed Consent Statement: Informed consent was obtained from all subjects involved in the study.

Data Availability Statement: Data are available on justify request to the corresponding author.

Acknowledgments: The authors would like to thank the teachers and students for their cooperation in this study.

Conflicts of Interest: The authors declare no conflict of interest. The funders had no role in the design of the study; in the collection, analyses, or interpretation of data; in the writing of the manuscript, or in the decision to publish the results.

\section{References}

1. Sharp, J.; Theiler, S. A review of psychological distress among university students: Pervasiveness, implications and potential points of intervention. Int. J. Adv. Couns. 2018, 40, 193-212. [CrossRef]

2. Leka, S.; Griffiths, A.; Cox, T. La Organización del Trabajo y el estrés: Estrategias Sistemáticas de la Solución de probLemas para Empleados, Personal Directivo y Representantes Sindicales; Organización Mundial de la Salud: Geneva, Switzerland, 2004. Available online: http:/ / www.who.int/occupational_health/publications/en/pwh3sp.pdf (accessed on 20 October 2021).

3. Misrachi-Launert, C.; Ríos-Erazo, M.; Manríquez-Urbina, J.M.; Burgos-Ibarra, C.; Ponce-Espinoza, D. Fuentes de estrés percibidas y rendimiento académico de estudiantes de odontología chilenos. FEM Rev. De La Fund. Educ. Médica 2015, 18, 109-116. [CrossRef]

4. Suárez-Monte, N.; Díaz-Subieta, L.B. Estrés académico, deserción y estrategias de retención de estudiantes en la educación superior. Rev. De Salud Pública 2015, 17, 300-313. [CrossRef] [PubMed]

5. García-Rojas, K.; Salazar-Salvatierra, E.; Barja-Ore, J. Resiliencia y estrés percibido en estudiantes de Obstetricia de una universidad pública de Lima, Perú. FEM Rev. De La Fund. Educ. Médica 2021, 24, 95-99. [CrossRef]

6. Álvarez-Arregui, E.; Pérez-Navío, E.; González-Fernández, R.; Rodríguez-Martín, A. Pedagogical Leaders and the TeachingLearning Processes in COVID-19 Times. Int. J. Environ. Res. Public Health 2021, 18, 7731. [CrossRef]

7. Elsalem, L.; Al-Azzam, N.; Jum'ah, A.A.; Obeidat, N.; Sindiani, A.M.; Kheirallah, K.A. Stress and behavioral changes with remote E-exams during the Covid-19 pandemic: A cross-sectional study among undergraduates of medical sciences. Ann. Med. Surg. 2020, 60, 271-279. [CrossRef]

8. Gamonal Limcaoco, R.S.; Montero Mateos, E.; Fernandez, J.M.; Roncero, C. Anxiety, worry and perceived stress in the world due to the COVID-19 pandemic. Preliminary results. medRxiv 2020. [CrossRef]

9. Rossi, R.; Socci, V.; Talevi, D.; Mensi, S.; Niolu, C.; Pacitti, F.; Di Marco, A.; Rossi, A.; Siracusano, A.; Di Lorenzo, G. COVID-19 pandemic and lockdown measures impact on mental health among the general population in Italy. An N=18147 web-based survey. Front. Psychiatry Adv. Online Publ. 2020, 11, 790. [CrossRef] [PubMed]

10. Correa, P.S.; Mola, D.J.; Ortiz, M.V.; Godoy, J.A. Variables relacionadas al estrés percibido durante el aislamiento por COVID-19 en Argentina. Salud Soc. 2021, 11, e4558. [CrossRef]

11. Ozamiz-Etxebarria, N.; Dosil-Santamaria, M.; Picaza-Gorrochategui, M.; Idoiagamondragon, N. Stress, anxiety, and depression levels in the initial stage of the COVID-19 outbreak in a population sample in the northern Spain. Niveles de estrés, ansiedad y depresión en la primera fase del brote del COVID-19 en una muestra recogida en el norte de España. Cad. De Saúde Pública 2020, 36, e00054020. [CrossRef]

12. León-Montoya, G.B.; Tejada-Muñoz, S.; Chotón-Calvo, M.d.R.; Saavedra-Chinchayán, M.E. Expectativas y actitudes frente al COVID-19 de estudiantes de enfermería de una universidad pública peruana. Rev. De La Univ. Del Zulia 2021, 12, 183-195. [CrossRef]

13. Wang, C.; Pan, R.; Wan, X.; Tan, Y.; Xu, L.; Ho, C.S.; Ho, R.C. Immediate psychological responses and associated factors during the initial stage of the 2019 coronavirus disease (COVID-19) epidemic among the general population in China. Int. J. Environ. Res. Public Health 2020, 17, 1729. [CrossRef]

14. Huang, Y.; Zhao, N. Generalized anxiety disorder, depressive symptoms and sleep quality during COVID-19 outbreak in China: A web-based cross-sectional survey. Psychiatry Res. 2020, 288, 112954. [CrossRef]

15. Khan, S.; Siddique, R.; Li, H.; Ali, A.; Shereen, M.A.; Bashir, N.; Xue, M. Impact of coronavirus outbreak on psychological health J. Glob. Health 2020, 10, 010331. [CrossRef]

16. Zhang, J.; Wu, W.; Zhao, X.; Zhang, W. Recommended psychological crisis intervention response to the 2019 novel coronavirus pneumonia outbreak in China: A model of West China Hospital. Precis. Clin. Med. 2020, 3, 3-8. [CrossRef]

17. Mc Gee, S.L.; Höltge, J.; Maercker, A.; Thoma, M.V. Sense of coherence and stress-related resil-ience: Investigating the mediating and moderat-ing mechanisms in the development of resilience following stress or adversity. Front. Psychiatry 2018, 9, 378. [CrossRef] [PubMed] 
18. Rectorado de la Universidad de Jaén. Comunicado Rectoral de 16 de Septiembre de 2021 Relativo al Establecimiento de la Modalidad Presencial en el Sistema de Docencia. 2021. Available online: https://www.ujaen.es/gobierno/viccom/ sites/gobierno_viccom/files/uploads/node_book/2021-09/Comunicado\%20rectoral\%20de\%2016-09-2021\%20relativo\%20 al\%20establecimiento\%20de\%20la\%20modalidad\%20presencial\%20en\%20el\%20sistema\%20de\%20docencia.pdf (accessed on 18 November 2021).

19. McDonald, R.P. Test Theory: A Unified Treatment; Lawrence Erlbaum Associates: Mahwah, NJ, USA, 1999.

20. Hair, J.; Hult, G.; Ringle, C.; Sarstedt, M. A Primer on Partial Least Square Structural Equation Modeling (PLS-SEM); Sage: Riverside County, CA, USA, 2017.

21. Stone, L.L.; Janssens, J.M.; Vermulst, A.A.; Van Der Maten, M.; Engels, R.C.; Otten, R. The Strengths and Difficulties Questionnaire: Psychometric properties of the parent and teacher version in children aged 4-7. BMC Psychol. 2015, 3, 4. [CrossRef]

22. Ruiz, M.A.; Pardo, A.; San Martin, R. Modelos de ecuaciones estructurales. Pap. Del Psicólogo 2010, 31, 34-45.

23. Henseler, J.; Ringle, C.M.; Sarstedt, M. A New Criterion for Assessing Discriminant Validity in Variance-based Structural Equation Modeling. J. Acad. Mark. Sci. 2015, 43, 115-135. [CrossRef]

24. Becker, J.-M.; Ringle, M.; Sarstedt, M. Estimating Moderating Effects in PLS-SEM and PLSc-SEM: Interaction Term Generation. J. Appl. Struct. Equ. Modeling 2018, 2, 1-21. [CrossRef]

25. Martínez-Ávila, M.; Fierro-Moreno, E. Aplicación de la técnica PLS_SEM en la gestión del conocimiento: Un enfoque técnico práctico. RIDE Rev. Iberoam. Para La Investig. Y Desarro. Educ. 2018, 8, 130-164. [CrossRef]

26. Norabuena-Mendoza, C.H.; Huamán-Osorio, A.P.; Ramírez-Asís, E.H. Modelo de Ecuaciones Estructurales (Con estimación PLS) basado en calidad de servicio y lealtad del Cliente de las Cajas Rurales Peruanas. Cienc. Adm. 2020, 81, 3-14. [CrossRef]

27. Chin, W.W. The partial least squares approach for structural equation modeling. In Modern Methods for Business Research; Marcoulides, G.A., Ed.; Lawrence Erlbaum Associates: Mahwah, NJ, USA, 1998; pp. 295-336.

28. Diener, E.; Emmons, R.A.; Larsen, R.J.; Griffin, S. The Satisfaction with Life Scale. J. Pers. Assess. 1985, 49, 71-75. [CrossRef] [PubMed]

29. Vázquez, C.; Duque, A.; Hervás, G. Satisfaction with Life Scale in a Representative Sample of Spanish Adults: Validation and Normative Data. Span. J. Psychol. 2013, 16, 1-15. [CrossRef]

30. Cohen, S.; Kamarck, T.; Mermelstein, R. A global measure of perceived stress. J. Health Soc. Behav. 1983, 24, 385-396. [CrossRef]

31. Remor, E. Psychometric Properties of a European Spanish Version of the Perceived Stress Scale (PSS). Span. J. Psychol. 2006, 9, 86-93. [CrossRef]

32. Guzmán-Yacaman, J.E.; Reyes-Bossio, M. Adaptación de la Escala de Percepción Global de Estrés en estudiantes universitarios peruanos [Adaptation of the Global Perceived Stress Scale in college peruvian students]. Rev. De Psicol. 2018, 36, 719-750. [CrossRef]

33. Domínguez-Lara, S.A.; Merino-Soto, C. ¿Por qué es importante reportar los intervalos de confianza del coeficiente alfa de Cronbach? Rev. Latinoam. De Cienc. Soc. Niñez Y Juv. 2015, 13, 1326-1328.

34. Matalinares, C.M.L.; Díaz, A.G.; Arenas, I.C.; Raymundo, V.O.; Baca, R.D.; Uceda, E.J.; Yaringaño, L.J. Afrontamiento al estrés y bienestar psicológico en estudiantes universitarios de Lima y Huancayo. Rev. De Investig. Psicol. 2017, 19, 123-143. [CrossRef]

35. Ginevra, M.C.; Magnano, P.; Lodi, E.; Annovazzi, C.; Camussi, E.; Patrizi, P.; Nota, L. The role of career adaptability and courage on life satisfaction in adolescence. J. Adolesc. 2018, 62, 1-8. [CrossRef]

36. Zuffianò, A.; Martí-Vilar, M.; López-Pérez, B. Prosociality and life satisfaction: A daily-diary investigation among Spanish university students. Pers. Individ. Differ. 2018, 123, 17-20. [CrossRef]

37. González-Olaya, H.L.; Delgado-Rico, H.D.; Escobar-Sánchez, M.; Cárdenas-Angelone, M.E. Asociación entre el estrés, el riesgo de depresión y el rendimiento académico en estudiantes de los primeros semestres de un programa colombiano de medicina. FEM Rev. De La Fund. Educ. Médica 2014, 17, 47-54.

38. Pérez-Navío, E.; Medina-Domínguez, M.C.; Cachón-Zagalaz, J. Perception of the professional competences of last year's students of Pre-Primary Education and Primary Education degrees and students of training Teachers Master. NAER. J. New Approaches Educ. Res. 2019, 8, 58-65. [CrossRef]

39. Fornés-Vives, J.; Garcia-Banda, G.; Frías-Navarro, D.; Rosales-Viladrich, G. Coping, stress, and personality in Spanish nursing students: A longitudinal study. Nurse Educ. Today 2016, 36, 318-323. [CrossRef]

40. Kline, R.B. Principles and Practice of Structural Equation Modeling; Guilford Press: New York, NY, USA, 2015.

41. Vargas-Halabí, T.; Mora-Esquivel, R. Adaptación y dimensionalidad de la escala DOCS en el contexto organizacional costarricense: Aplicación de la entrevista cognitiva y el análisis factorial confirmatorio/ Adaptation and Dimensionality of the DOCS Scale in the Costa Rican Organizational Context: An Application of the Cognitive Interview and of Confirmatory Factor Analysis. Rev. Costarric. De Psicol. 2017, 36, 199-226. [CrossRef]

42. Iacobucci, D. Structural equations modeling: Fit indices, sample size, and advanced topics. J. Consum. Psychol. 2010, 20, 90-98. [CrossRef]

43. Medrano, L.A.; Muñoz-Navarro, R. Aproximación Conceptual y Práctica a los Modelos de Ecuaciones Estructurales. Rev. Digit. De Investig. En Docencia Univ. 2017, 11, 219-239. [CrossRef]

44. Ramery-Gelpi, E.; Pérez Navío, E. Comparación de la satisfacción laboral del director escolar y los docentes. Rev. Electrón. De Investig. Y Docencia (REID) 2016, 15, 85-100. [CrossRef] 
45. Medina Rivilla, A.; Pérez Navío, E. Evaluación de la Práctica Docente: Modelos, Criterios y Pruebas. Estudio de casos de la evaluación de la enseñanza de la medicina. En A. Medina y M. Secchi. In Didáctica Aplicada a la Medicina y Ciencias de la Salud; Amalevi: Rosario, Argentina, 2010; pp. 353-387. ISBN 9-789872-444112. Available online: https://www.iunir.edu.ar/ publicaciones/libros/didactica\%20aplicada.pdf (accessed on 5 October 2021).

46. Dymecka, J.; Gerymski, R.; Machnik-Czerwik, A. How does stress affect our life satisfaction during COVID-19 pandemic? Moderating mediation analysis of sense of coherence and fear of coronavirus. Psychol. Health Med. 2021. [CrossRef] [PubMed]

47. Yang, C.; Chen, A.; Chen, Y. College students' stress and health in the COVID-19 pandemic: The role of academic workload, separation from school, and fears of contagion. PLoS ONE 2021, 16, e0246676. [CrossRef]

48. Antelm-Lanzat, A.M.; Gil, A.J.; Cacheiro-González, M.L.; Pérez-Navío, E.; Fonseca-Pedrero, E. Learning styles and vocational guidance in secondary education. Educ. Sci. Theory Pract. 2020, 20, 1-15. [CrossRef] 